\title{
MUMPS OUTBREAK AMONG THE MILITARY IN LUXEMBOURG IN 2008: EPIDEMIOLOGY AND EVALUATION OF CONTROL MEASURES
}

\author{
J Mossong (joel.mossong@Ins.etat.lu) ${ }^{1}$, Ch Bonert ${ }^{2}$, P Weicherding ${ }^{3}$, M Opp1, P Reichert ${ }^{1}$, J Even1, F Schneider ${ }^{1}$ \\ 1. Laboratoire National de Santé (National Health Laboratory), Unité de microbiologie (Microbiology Unit), Luxembourg \\ 2. Service de Santé de l’Armée (Army Health Service), Centre militaire (Military Centre), Diekirch, Luxembourg \\ 3. Direction de la Santé (Directorate of Health), Inspection Sanitaire (Sanitary Inspection), Luxembourg
}

\begin{abstract}
In the last quarter of 2008, an outbreak of mumps occurred in Luxembourg affecting initially 10 young adults at a military centre. Following a mass vaccination campaign, no further clinical cases were observed. $90 \%$ of 136 vaccine recipients were IgG positive one month after vaccination compared to $54 \%$ before vaccination. Until 31 December 2008, 19 mumps cases were also reported from the community. The outbreak strain belonged to genogroup $\mathrm{G}$.
\end{abstract}

\section{Introduction}

During the last three months of 2008 , an outbreak of mumps occurred in Luxembourg with 29 suspected clinical cases reported until 31 December 2008. Prior to this outbreak, the last time a mumps case was reported to the health authorities was in 2005.

Mumps is an acute viral infection characterised by swelling of the salivary glands and particularly the parotid glands. Asymptomatic cases occur quite frequently (up to $30 \%$ of all cases) and symptoms can be flu-like. The most frequently observed complications include inflammation of genital glands (testicles or ovaries), pancreatitis as well as aseptic meningitis. Mumps can be prevented by vaccination which was introduced to the routine schedule in Luxembourg in 1986-7 with trivalent measles, mumps, rubella vaccine (MMR) for children aged 15 to 18 months. A recommendation for a second dose at the age of 5-6 years was released in October 1994.

Following the incidence of 10 cases in different units at a military centre in Luxembourg in September and October 2008, the Military Command, the Army Health Service and the Health Inspection decided to organise a vaccination campaign for personnel in all units working on this particular military site, which also included personnel and trainees of the Luxembourg Police Force. At the same time it was decided together with the National Health Laboratory to conduct a sero-epidemiological survey with the aim to determine seroprevalence against mumps virus in this army population and to study risk factors for being seronegative.

\section{Methods}

For the purpose of the outbreak investigation at the military centre, the following case definition criteria stated by the Centers for Disease Control and Prevention (CDC) were used [1]. A clinical case was defined as a patient with acute onset of unilateral or bilateral tender, self-limited swelling of the parotid or other salivary gland(s), lasting at least two days, and without other apparent cause. Laboratory criteria for diagnosis were isolation of mumps virus from clinical specimen, detection of mumps nucleic acid by real-time PCR, or detection of mumps IgM antibodies.

Following the decision to hold a vaccination campaign, all army and police personnel working onsite were briefed about the cases and the current situation of the mumps epidemic, recommended to participate in the vaccination campaign (on a voluntary basis) and explained the reasons and usefulness of the sero-epidemiological study. The blood sample collection was organised at the Army Health Service onsite in collaboration with the National Health Laboratory upon receipt of written informed consent forms. The samples were immediately transported to the National Health Laboratory where they were prepared and stored for future analysis. A quantitative IgG and IgM assay (Genzyme Virotech, Rüsselsheim, Germany) was used to determine the presence of anti-mumps antibodies according to the manufacturer's instruction. A real-time PCR assay was implemented to detect mumps virus in throat swaps/oral fluid and followed by sequencing of the positive samples [2,3].

\section{Results}

\section{The epidemic}

Figure 1 shows the evolution of the mumps epidemic in Luxembourg up to the end of the year 2008. Following the vaccination campaign which began on 28 October 2008, no further clinical cases have been observed at the military centre, but several clinical cases were reported in the "civilian" population in Luxembourg.

The age distribution of reported cases shown in Figure 2 reveals that the large majority (23 of 29 or $79 \%$ ) were aged between 15 and 34 years. Seven of the reported 29 (24\%) cases were female.

Of 13 oral or throat swabs taken from suspected clinical mumps cases, six were positive by PCR (out of which five could also be cultured). Nucleotide sequencing showed that the strain belonged to genogroup $\mathrm{G}$ which has been observed recently in Bavaria, Germany (May-July 2008), the United States (2006) and the United Kingdom and Ireland (2004-05). 
Detailed clinical data are available for the 10 cases reported at the military centre. Eight patients had a classical presentation with parotitis, predominantly right-sided. Of those eight cases, five had never been vaccinated, one had received a single dose and two had received two doses of a MMR vaccine. The two patients with non-specific symptoms and positive IgM test results had received two vaccine doses. Two patients hospitalised with suspected viral meningitis recovered without sequelae.

\section{Sero-epidemiological study at the military centre}

225 participants including 26 women (12\%) agreed to give a blood sample prior to the vaccine administration by informed written consent. Of these, 134 (60\%) had a positive IgG result, 37 (16\%) had a borderline IgG result and 54 (24\%) had a negative IgG result. The majority, 219 (97\%) participants were IgM negative, five $(2 \%)$ were IgM borderline, and one participant had a positive IgM result.

The IgG seroprevalence rate varied significantly with age participants born before 1970 had higher seroprevalence (81\%) compared to participants born after 1970 (53\%, $p=0.006)$.

For participants with a documented vaccination history, IgG seroprevalence did not vary significantly as a function of the number of received doses $(p=0.19)$.

Of the 225 participants, 136 (60\%) gave a second blood sample on average 31 days after administration of the Priorix $®$ vaccine. $123(90 \%)$ were IgG positive, six (4\%) were IgG borderline and seven (5\%) were IgG negative. Of 37 participants who were initially IgG negative, 24 (65\%) became IgG positive, six (16\%) were IgG borderline and seven (19\%) remained IgG negative one month after vaccination. All 25 participants who were initially IgG borderline became IgG positive and all 74 participants who were initially IgG positive remained positive.

At the second sampling opportunity, four (3\%) participants were IgM positive (they were initially IgG and IgM negative), three (2\%) were IgM borderline (two had also been initially lgM borderline and one negative), and 129 (95\%) participants were IgM negative.

F I G U R E 1

Epidemic curve of reported mumps cases in Luxembourg, 2008 $(n=29)$

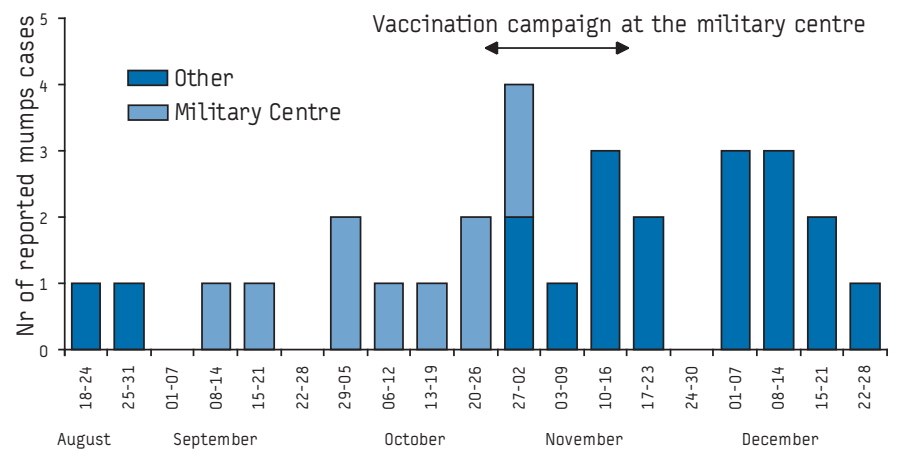

F I G U R E 2

Age distribution of reported mumps cases in Luxembourg, 2008 $(\mathbf{n}=29)$

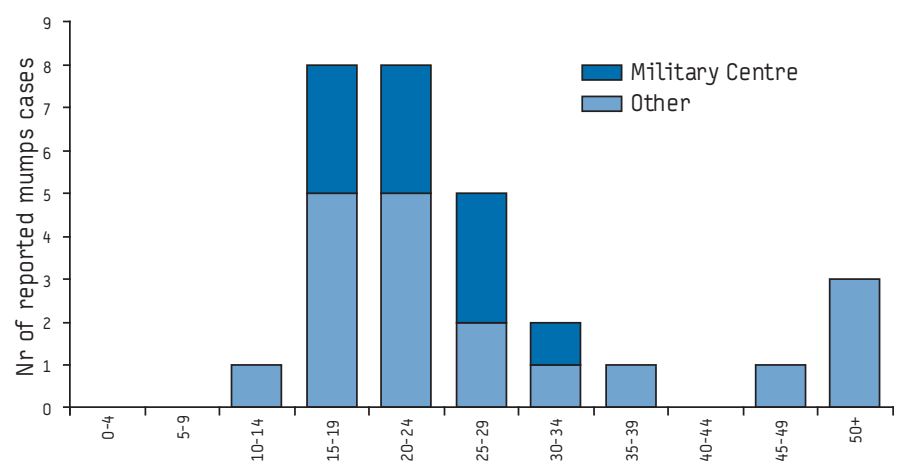

T A B L E 1

Sero-epidemiological study of mumps at a military centre in Luxembourg, 2008. IgG results by year of birth (chi2 test, $\mathrm{p}=0.006$ )

\begin{tabular}{|l|c|c|c|}
\hline Year of birth & negative & borderline & positive \\
\hline$<1970$ & $6(11 \%)$ & $4(7 \%)$ & $44(81 \%)$ \\
\hline $1970-83$ & $19(33 \%)$ & $8(14 \%)$ & $30(53 \%)$ \\
\hline $1984-86$ & $15(27 \%)$ & $10(18 \%)$ & $31(55 \%)$ \\
\hline $1987-90$ & $14(24 \%)$ & $15(26 \%)$ & $29(50 \%)$ \\
\hline Total & $54(24 \%)$ & $37(16 \%)$ & $134(60 \%)$ \\
\hline
\end{tabular}

T A B L E 2

Sero-epidemiological study of mumps at a military centre in Luxembourg, 2008. IgG results by number of measles, mumps, rubella (MMR) vaccine doses received before the onsite vaccination campaign (chi2 test, $\mathrm{p}=0.19$ )

\begin{tabular}{|l|c|c|c|}
\hline Number of doses & negative & borderline & positive \\
\hline 0 & $24(19 \%)$ & $19(15 \%)$ & $81(65 \%)$ \\
\hline 1 & $14(39 \%)$ & $5(14 \%)$ & $17(47 \%)$ \\
\hline 2 & $14(25 \%)$ & $11(20 \%)$ & $31(55 \%)$ \\
\hline 3 & $0(0 \%)$ & $1(50 \%)$ & $1(50 \%)$ \\
\hline Total & $52(23 \%)$ & $36(16 \%)$ & $130(59 \%)$ \\
\hline
\end{tabular}

T A B L E 3

Sero-epidemiological study of mumps at a military centre in Luxembourg, 2008. Comparison of IgG results before and one month after the vaccination campaign

\begin{tabular}{|l|c|c|c|c|}
\hline & \multicolumn{4}{|c|}{ IgG after vaccination } \\
\hline IgG before vaccination & negative & borderline & positive & Total \\
\hline negative & 7 & 6 & 24 & 37 \\
\hline borderline & 0 & 0 & 25 & 25 \\
\hline positive & 0 & 0 & 74 & 74 \\
\hline Total & 7 & 6 & 123 & 136 \\
\hline
\end{tabular}




\section{Discussion}

Our study reveals that, following several years of absence, mumps virus has re-emerged in Luxembourg in the last term of 2008. This is not surprising as other countries in Europe and North America have also witnessed relatively sizable mumps outbreaks in recent years [4-13].

In our case, most reported cases occurred in young adults. More than half of the staff on the military site was born before the introduction of the combined MMR vaccine in 1986 and the majority of reported clinical mumps cases had never received vaccination. Whereas most persons born before 1970 have naturally acquired immunity, persons born between 1970 and 1985 have had less exposure to mumps virus (due to the reduction of mumps circulation after the MMR vaccine was introduced into the vaccination schedule in 1986) and have never been targeted by a "mop-up" vaccination campaign. Moreover, our data seem to suggest that a sizable fraction of persons born between 1986 and 1990 (49\% of participants) have not received the recommended two doses of MMR vaccine. This could be explained by the fact that the official recommendation of a second dose of MMR was only issued in 1994, eight years after the introduction of MMR vaccine.

The vaccination campaign at the military centre appears to have led to a large reduction of viral transmission as no further clinical cases have been observed at the site. Following vaccination, 90\% of the study participants were IgG positive compared with $54 \%$ before vaccination. Even if the sensitivity of our serological assay is slightly problematic (due to a high proportion of borderline results), a quantitative analysis seems to suggest that « borderline " results can be boosted by vaccination, from a mean of 10 Virotech units to 18 units.

Another interesting aspect of this incident is that the rapid implementation of the vaccination campaign at the military centre was an ideal real-life exercise for the influenza pandemic. Our experience suggests that in the right conditions, a doctor assisted by two technicians (one for the preparation of the vaccine and one for paper work) can administer vaccines to approximately 150 persons in half a day.

Although the sample size in our study is quite limited, our data suggest that a single dose of Priorix ${ }^{\circledR}$ vaccine could be immunogenic (i.e. induced a positive or borderline IgG result) in approximately $80 \%$ of previously seronegative adults. While some authors have suggested that waning immunity may contribute to mumps outbreaks in older vaccinated populations [6], the large majority of our cases have no history of vaccination. If waning of immunity was more prevalent, we would also expect the outbreak to spread to younger vaccinated generations (who go to secondary schools where a lot of mixing occurs [14]) and this has not (yet) been observed.

To stop the circulation of mumps virus in the long term in Luxembourg, we suggest that a MMR campaign aimed at all persons* born between 1970 et 1990 who have not received two doses of vaccine or who do not have protective antibody levels would be necessary to protect their health. Such a campaign could also have an additional advantage of increasing population immunity against rubella and measles which have been targeted for elimination by the World Health Organization (WHO) European Region by 2010. In addition, further measures are probably necessary to document and possibly raise levels of two dose coverage with the MMR vaccine in adolescents and children born after 1990
*Note: While respecting vaccine manufacturer's contraindications, particularly in women: no current or pregnancy planned for 3 months after vaccination.

\section{Aknowledgements}

We would like to thank the Military Command, the Police Academy and all involved members of staff at the LNS for helping to organise the sero-epidemiological survey at short notice.

\section{References}

1. Centers for Disease Control and Prevention. Mumps Case Definition and Case Classification. 2008. Available from: http://www.cdc.gov/vaccines/vpd-vac/ mumps/outbreak/case-def.htm

2. Krause $\mathrm{CH}$, Eastick K, Ogilvie MM. Real-time PCR for mumps diagnosis on clinical specimens--comparison with results of conventional methods of virus detection and nested PCR. J Clin Virol. 2006;37(3):184-9.

3. Boddicker JD, Rota PA, Kreman T, Wangeman A, Lowe L, Hummel KB, et al. Realtime reverse transcription-PCR assay for detection of mumps virus RNA in clinical specimens. J Clin Microbiol. 2007 Sep;45(9):2902-8.

4. Bernard H, Schwarz NG, Melnic A, Bucov V, Caterinciuc N, Pebody RG, et al. Mumps outbreak ongoing since October 2007 in the Republic of Moldova. Euro Surveill. 2008;13(13):pij=8079. Available from: http://www.eurosurveillance. org/ViewArticle. aspx?ArticleId $=8079$

5. Boxall N, Kubínyiová M, Príkazský V, Beneš C, Cástková J. An increase in the number of mumps cases in the Czech Republic, 2005-2006. Euro Surveill. 2008;13(16):pii=18842. Available from: http://www.eurosurveillance.org/ ViewArticle.aspx?ArticleId $=18842$

6. Cohen C, White JM, Savage EJ, Glynn JR, Choi Y, Andrews N, et al. Vaccine effectiveness estimates, 2004-2005 mumps outbreak, England. Emerg Infect Dis. 2007;13(1):12-7.

7. Dayan GH, Quinlisk MP, Parker AA, Barskey AE, Harris ML, Schwartz JM, et al. Recent resurgence of mumps in the United States. N Engl J Med. 2008 Apr 10;358(15):1580-9.

8. Gee S, O'Flanagan D, Fitzgerald M, Cotter S. Mumps in Ireland, 2004-2008. Euro Surveill. 2008;13(18):pii=18857. Available from: http://www.eurosurveillance. org/ViewArticle.aspx?ArticleId $=18857$

9. Gerstel L, Lenglet A, García Cenoz M. Mumps outbreak in young adults following a village festival in the Navarra region, Spain, August 2006. Euro Surveill. 2006;11(45):pii=3078. Available from: http://www.eurosurveillance. org/ViewArticle.aspx?ArticleId=3078

10. Karagiannis I, van Lier A, van Binnendijk R, Ruijs H, Fanoy E, Conyn-Van Spaendonck MA, et al. Mumps in a community with low vaccination coverage in the Netherlands. Euro Surveill. 2008:13(24):pii=18901. Available from: http:// www.eurosurveillance.org/ViewArticle.aspx?ArticleId=18901

11. Sartorius B, Penttinen P, Nilsson J, Johansen K, Jönsson K, Arneborn M, et al. An outbreak of mumps in Sweden, February-April 2004. Euro Surveill. 2005;10(9):pii=559. Available from: http://www.eurosurveillance.org/ ViewArticle.aspx?ArticleId $=559$

12. Schmid D, Holzmann $H$, Alfery $C$, Wallenko $H$, Popow-Kraupp TH, Allerberger F. Mumps outbreak in young adults following a festival in Austria, 2006. Euro Surveill. 2008;13(7):pii=8042. Available from: http://www.eurosurveillance. org/ViewArticle.aspx?ArticleId $=8042$

13. Szomor K, Molnár Z, Huszti G, Ozsvárné Csepregi É. Local mumps outbreak in Hungary, 2007. Euro Surveill. 2007;12(13):pii=3167. Available from: http://www. eurosurveillance.org/ViewArticle.aspx?ArticleId=3167

14. Mossong J, Hens N, Jit M, Beutels P, Auranen K, Mikolajczyk R, et al. Social contacts and mixing patterns relevant to the spread of infectious diseases. PLoS Med. 2008;5(3): 74.

This article was published on 19 February 2009.

Citation style for this article: Mossong J, Bonert C, Weicherding P, Opp M, Reichert $P$, Even J, Schneider F. Mumps outbreak among the military in Luxembourg in 2008 : epidemiology and evaluation of control measures . Euro Surveill. 2009;14(7):pii=19121. Available online: http://www.eurosurveillance.org/ViewArticle. aspx?ArticleId=19121 